\title{
Groundwater Conditions and Hydrogeochemistry of the Sombreiro-Warri Deltaic Plain Deposit (Shallow Benin Formation) in the Vicinity of Agbarho, Nigeria
}

\author{
O. Efobo ${ }^{1 *}$, F. C. Ugbe $^{2}$, I. A. Akpoborie ${ }^{2}$ \\ ${ }^{1}$ Center for Research in Environmental Resource Management, Abraka, Nigeria \\ ${ }^{2}$ Department of Geology, Delta State University, Abraka, Nigeria
}

Received 27 January 2020, accepted in final revised form 19 May 2020

\begin{abstract}
Groundwater conditions and hydrogeochemistry in the Sombreiro-Warri Deltaic Plain deposit at the Agbarho area were described with the aid of data obtained from dug wells. Ten dug wells and two surface water locations were sampled for water quality analysis. Regional groundwater flow is from the northeast to southwest direction with local distortion resulting from sustained groundwater withdrawal in more populated areas of the town. $\mathrm{pH}$ in surface water range was from 4.9 to 5.4 and that of groundwater from 3.8 to 5.9. TDS in groundwater and surface water ranges were from 39.6 to $123 \mathrm{mg} / \mathrm{L}$ and 9 to $25.6 \mathrm{mg} / \mathrm{L}$, respectively. Two hydrochemical facies, magnesium chloride and sodium chloride facies were defined in this study. The order of abundance of cations are $\mathrm{Mg}>\mathrm{Na}+\mathrm{K}>\mathrm{Ca}$, $\mathrm{Na}+\mathrm{K}>\mathrm{Mg}>\mathrm{Ca}$ and $\mathrm{Na}+\mathrm{K}>\mathrm{Ca}>\mathrm{Mg}$ and for anions is $\mathrm{Cl}>\mathrm{HCO}_{3}>\mathrm{SO}_{4}$. This study indicates that the groundwater chemistry is controlled largely by precipitation. Water qualities from the dug wells and surface water are well within the SON permitted levels except faecal coliform occurring at minimal level in two wells and one of the locations on the river.
\end{abstract}

Keywords: Groundwater; Major ions; Water quality; Sombreiro-warri deltaic plain; Benin formation; Agbarho; Niger delta.

\begin{abstract}
(C) 2020 JSR Publications. ISSN: 2070-0237 (Print); 2070-0245 (Online). All rights reserved. doi: http://dx.doi.org/10.3329/jsr.v12i4.45187 J. Sci. Res. 12 (4), 633-643 (2020)
\end{abstract}

\section{Introduction}

Agbarho is located in the western Niger Delta petroleum province along the East-West road some $12 \mathrm{~km}$ eastward from Warri, a major hub of the petroleum industry in Nigeria. The town is a cluster of several communities with its headquarter situated at OrhorAgbarho. The area is underlain by the Sombreiro-Warri Deltaic Plain (SWDP) deposit and is rich with abundance of water resources. The deposits of the SWDP and the underlying Benin Formation are exploited for water supply: inexpensive shallow dug wells that tap the SWDP are favored by the majority of the residents while deeper boreholes exploit the Benin Formation. The SWDP deposit has distinct hydraulic characteristics but is indistinguishable from the Benin Formation proper in the subsurface [1,2] and supplies water to wells everywhere it occurs in the Niger Delta. The permeability of sand in the

*Corresponding author: oefobo@gmail.com 
SWDP is in a range of $3.1 \times 10^{-4} \mathrm{~m} / \mathrm{sec}[3,4]$. However, the quality of water from shallow dug wells is such that it does require some prior treatments before use for domestic purposes [5-9].

The Agbarho River which stretches from the northwest to southwest along the edge of the town also serves as important source of water supply. A quantitative description of the river system is difficult because of the absence of flow data. However, the similar size Adofi River located northeast of the area which also flows through the SWDP terrain delivers a six-year annual average of $0.85 \times 10^{9} \mathrm{~m}^{3}$ of water from an effective catchment area of about $425 \mathrm{~km}^{2}$ [9].

The need to continuously monitor the quality of water drawn from these dug wells have become imperative as it is a main source of water supply in this rapidly expanding town that is witnessing growth due to its close proximity to the city of Warri. Thus, the primary objective of this investigation is; firstly, to develop a geo-reference groundwater gradients for the area, secondly, to define the hydrogeochemistry of the groundwater in the area and thirdly, to determine the suitability of surface water and groundwater for domestic use. In addition, the results will support decision-making and policies for managing water resources in the area and add to the current knowledge of the water resource potential of the Sombreiro-Warri Deltaic Plain deposit that constitute and is indeed the shallow Benin Formation.

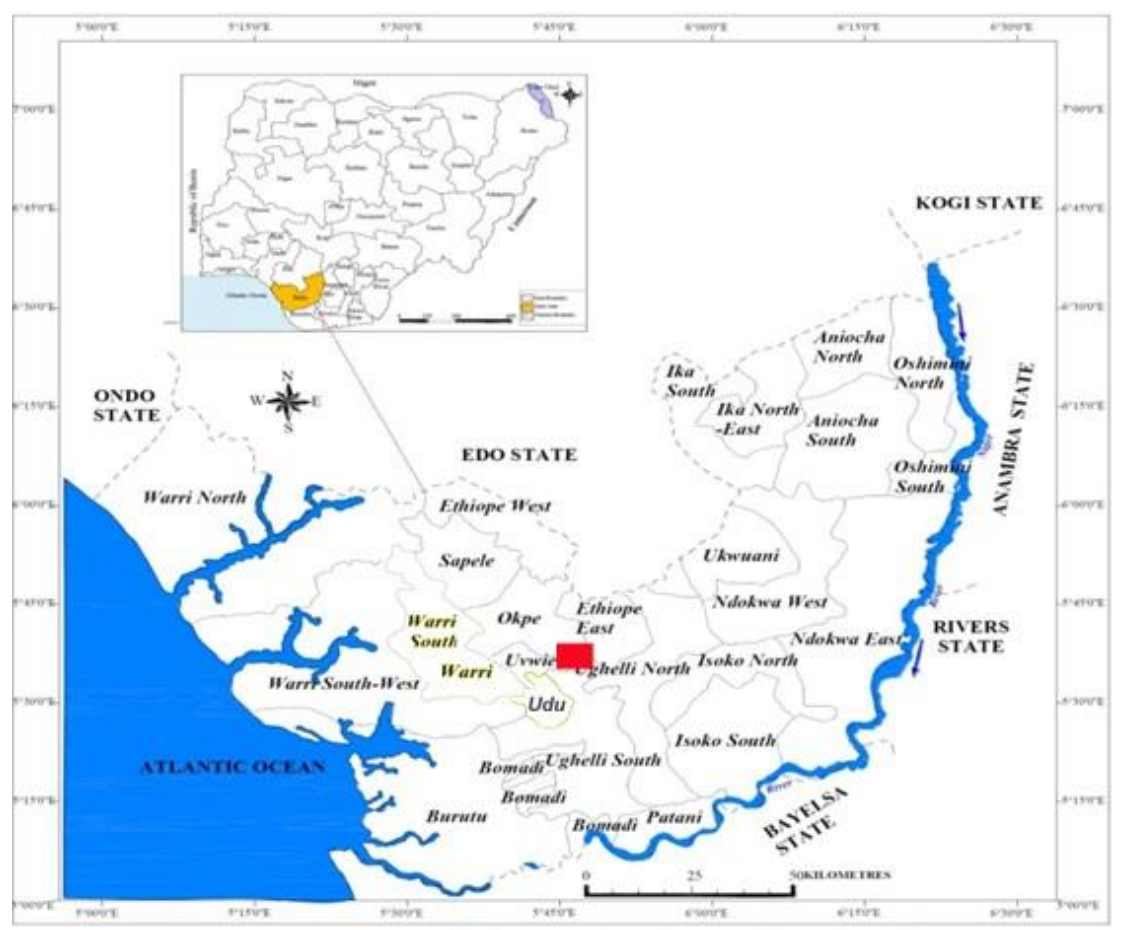

Fig. 1. Map of Delta State Nigeria showing location of study area (marked in red). Inset is a map of Nigeria showing the location of Delta State. 


\subsection{Area of study}

The study area (Fig. 1) lie roughly between latitude $5^{\circ} 31^{\prime} \mathrm{N}-5^{\circ} 37^{\prime} \mathrm{N}$ and longitude $5^{\circ}$ $48^{\prime} \mathrm{E}-5^{\circ} 54^{\prime} \mathrm{E}$ and is about $12 \mathrm{~km}$ from the city of Warri. It is made-up of several communities which include Oguname, Ohrerhe, Orhokpokpor and Orho-Agbarho (Administrative Headquarter) and seat of the Osuvie of Agbarho, the traditional ruler and the head of the town.

\subsection{Physiography and climate}

The Agbarho area is a typical Sombreiro-Warri Deltaic Plain terrain which is lowland, generally flat and slopes gently southward towards the ocean. The area is drained mainly by the Agbarho River which runs from the northwest to the southwestern corner of the town and flows to Warri where it is known as the Warri River. The area falls within the equatorial climate belt with temperature range of $23-37^{\circ} \mathrm{C}$ and relative humidity of 50-70 $\%$ [10]. The dry season runs from about December to February, and wet season from March to November with mean annual rainfall of 2500-3000 mm [11].

\subsection{Regional geology}

The area is part of the broader Niger Delta basin (Fig. 2) that has been studied extensively [12-16] and consist of three formations: from the youngest to the oldest, the Benin Formation, the Agbada Formation and the Akata Formation. Specifically, Agbarho is underlain by the Sombreiro-Warri Deltaic Plain (SWDP) deposit. The SWDP deposits consist of a sequence of fine to medium grained sand, coarse sands, silty and thin discontinuous clay layers that merge conformably in the sub surface with the continental/fluvial sands and gravels of the Benin Formation proper [9].

\section{Methodology}

Ten dug wells in the town were randomly selected for groundwater sampling. Two surface water sampling locations were also selected on the Agbarho River. Water samples from the ten selected dug wells and samples from two surface water locations were collected and stored in sterilized polyethylene bottles. Samples marked for heavy metal analysis were stabilized in situ with nitric acid. Total dissolved solids together with electrical conductivity were measured in situ using the TDS and HACH Conductivity meters respectively. $\mathrm{pH}$ of the samples was measured with the Schott Gerate $\mathrm{pH}$ meter. The PyeUnicam Atomic Absorption Spectrophotometer SP 2900 was used in determining heavy metals while $\mathrm{Na}$ and $\mathrm{K}$ concentrations were determined with a Jenway Clinical flame photometer. The $\mathrm{HACH}$ Spectrophotometer was used in determining $\mathrm{NO}_{3}$ ion using the cadmium reduction method. Sulphate concentration was obtained by turbidimetric methods and $\mathrm{Ca}, \mathrm{Mg}, \mathrm{HCO}_{3}$ and $\mathrm{Cl}$ were determined with appropriate titrimetric methods 
[17]. Total and faecal coliform were obtained using the multiple tube fermentation method [17] express as number of coliform per $100 \mathrm{~mL}$ of water.

Thirteen dug wells (Table 1) were also selected for depth to water level measurements. The depth to water level at each dug well was measured with an electronic water level indicator. The Garmin 72H GPS model instrument was used to determine the coordinates of each dug well position. The mean elevation readings from three GPS instrument employed at each location were used as elevation of each well position. Golden Software [18] Surfer 8 (Surface and Terrain Modeling tool) was employed in generating the water table head distribution.

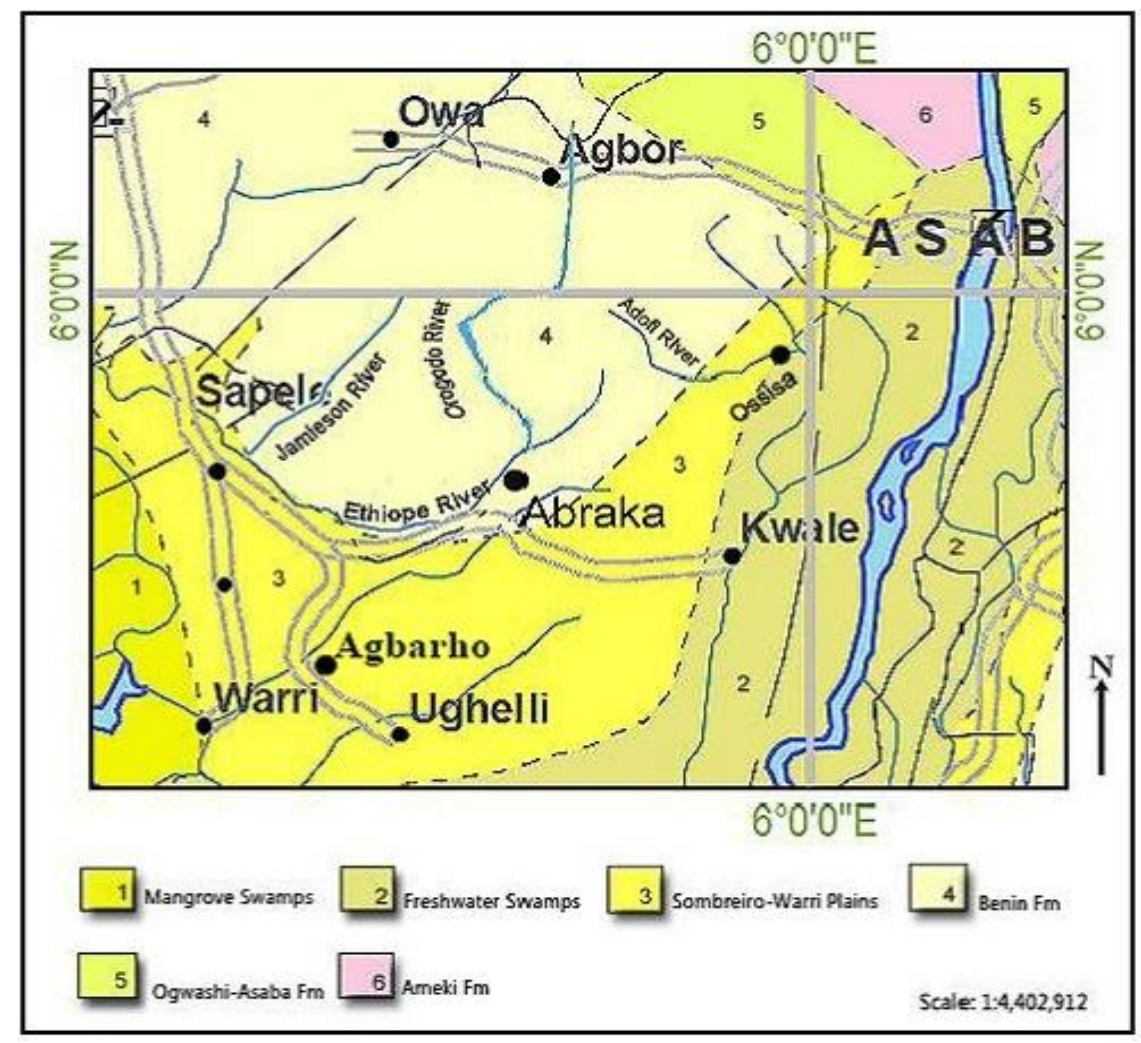

Fig. 2. Regional Geology of part of the Western Niger Delta showing the Agbarho area (modified from [19]).

\section{Results and Discussion}

\subsection{Groundwater conditions}

Data obtained from the depth to water level measurements (Table 1) were used to plot the water table contour lines as shown in Fig. 3. Groundwater occurs under water table conditions in the Agbarho area. Depth to water table varies from a minimum of $1.2 \mathrm{~m}$ at 
Agbarho Timber Market through $3 \mathrm{~m}$ at Ekrebe Unuode to a maximum of $6.45 \mathrm{~m}$ at Okotie Avenue. The water table map revealed presence of a groundwater mound situated in the northern part of the area in which water is flowing in all directions as well as west and southwest into the Agbarho River. There also appears to be another groundwater mound at Orhokpokpor area as well as another at the Unity School area to the east. Regional groundwater flow is from the northeast to southwest direction. The effect of continuous groundwater withdrawal in more populated area in the central and clearly older core part of the town has created local distortions on the regional groundwater flow. Similar local distortions on the regional northeast-southwest trend have been observed in the western Niger Delta $[8,9,20]$.

Table 1. Depth to water level measurements.

\begin{tabular}{llllcc}
\hline Eastings & Northings & Location & Well Type & DWL & Head \\
\hline 5.867528 & 5.587472 & *Ekrebe Unuode & Dug Well & 3 & 9 \\
5.864889 & 5.58275 & Old Ugh/Oviri Rd. & Dug Well & 4 & 17 \\
5.8805 & 5.580361 & "Unity Sch. Agbarho & Dug Well & 2.18 & 20.82 \\
5.85175 & 5.581833 & "General Hospital & Dug Well & 6.3 & 5.7 \\
5.855083 & 5.585639 & * Okotie Avenue & Dug Well & 6.45 & 7.4 \\
5.857472 & 5.584361 & Orhokpokpor Str. & Dug Well & 4.25 & 16.75 \\
5.862139 & 5.583222 & "Ekrerhervwe Str. & Dug Well & 3.66 & 5.34 \\
5.862694 & 5.59807 & * Obada Str. & Dug Well & 3.3 & 27.7 \\
5.862694 & 5.598917 & Odere Str. & Dug Well & 4.9 & 16.1 \\
5.858472 & 5.603083 & *Okan & Dug Well & 4.9 & 12.1 \\
5.8685 & 5.591694 & *Akpovi Avenue & Dug Well & 3.3 & 10.7 \\
5.8785 & 5.587333 & Agbarho Timber Market & Dug Well & 1.2 & 11.8 \\
5.858056 & 5.588 & *Agbarho Town Hall & Dug Well & 3.7 & 7.3 \\
5.86125 & 5.594583 & * OgboruAkpoguma Str. & Dug Well & - & - \\
\hline
\end{tabular}

* Groundwater sampling locations

\subsection{Water chemistry}

\subsubsection{Characteristics of surface water and groundwater}

Surface water and groundwater from dug wells in the Agbarho area is mainly used for domestic purposes and as previously mentioned several health implications have been raised with respect to these usages without prior treatment. Table 2 shows the physical and chemical characteristics of surface water from two locations on the Agbarho River and associated sampling locations (Fig. 4). TDS level is low with a range of 9 to 25.6 $\mathrm{mg} / \mathrm{L}$. The $\mathrm{pH}$ of river water is slightly acidic and ranges from 4.9 to 5.6. The TDS and $\mathrm{pH}$ levels are in agreements with results of other rivers in the region [22]. The low $\mathrm{pH}$ in the river is as a result of the impact of gas flaring in the Niger Delta [22]. The major cations $\mathrm{Na}^{+}, \mathrm{K}^{+}, \mathrm{Ca}^{2+}$ and $\mathrm{Mg}^{2+}$ are well below the Maximum Permitted Limits (MPLs) specified in the Standards Organization of Nigeria (SON) Drinking Water Standards [23]. Similarly, major anions $\mathrm{HCO}_{3}^{-} \mathrm{Cl}^{-} \mathrm{SO}_{4}{ }^{2-}$ and $\mathrm{NO}_{3}$ are also below the MPLs. The concentration levels of lead, cadmium and chromium in surface water were compared with the MPLs. As shown in Table 2, Cd occurs at levels that were below the MPL of 
$0.003 \mathrm{mg} / \mathrm{L}$, while $\mathrm{Pb}$ and $\mathrm{Cr}$ were not detected in the surface water. With respect to the microbial content, faecal coliform was detected at ST2 with a count of $3 \mathrm{cfu} / 100 \mathrm{~mL}$ which may be attributed to human and animal waste coming in contact with water body.

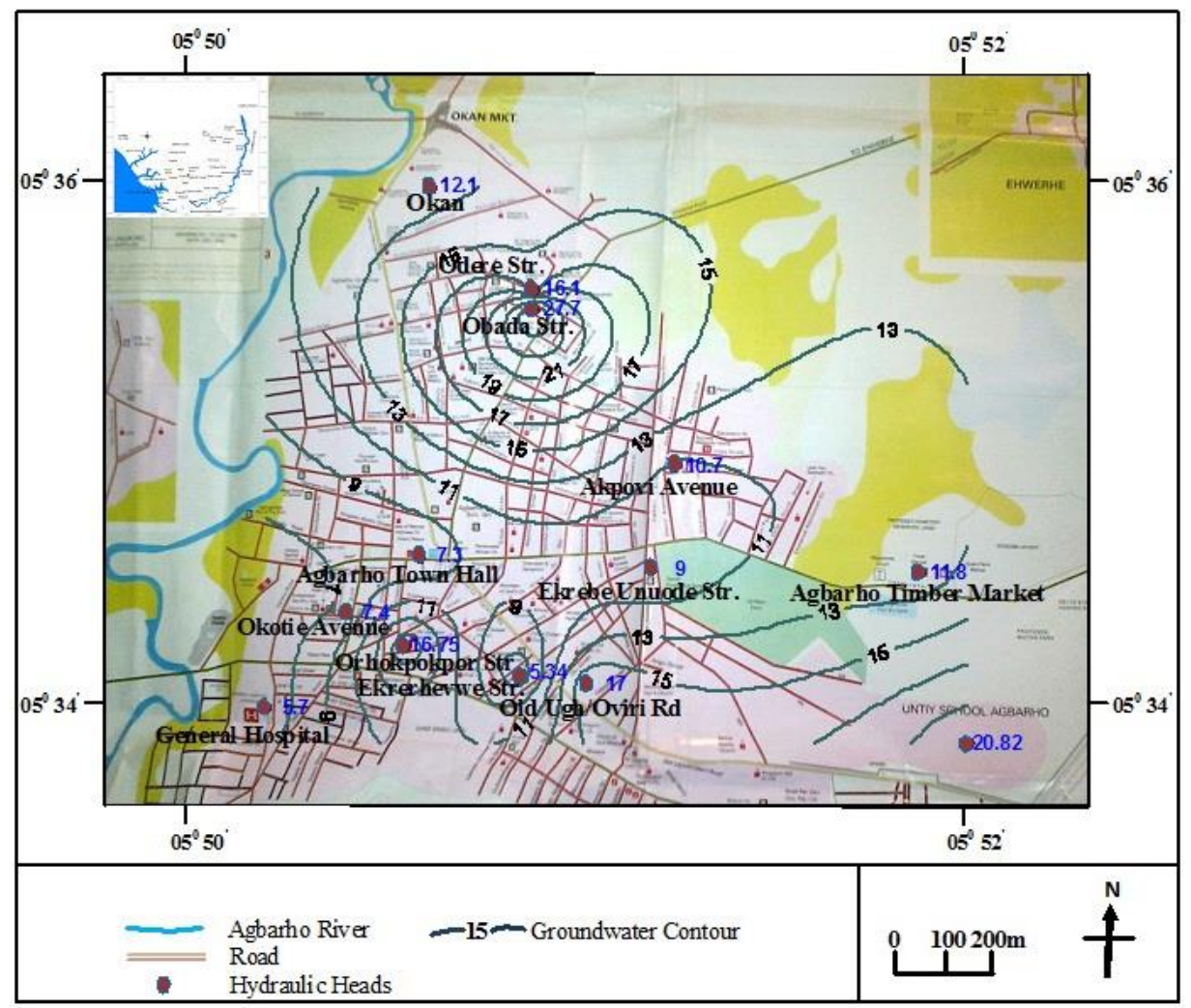

Fig. 3. Groundwater head distributions and contour lines (base map modified from [21]).

The physical and chemical characteristics of groundwater collected from the ten dug wells are shown in Table 3, and the spatial distributions of the groundwater sample locations are shown in Fig. 4. The pH values range from 3.8 at Ekrebe Unoude through 5.0 at Okotie Avenue and Agbarho Town Hall to a maximum of 5.9 at Okan with an average of 5.3 which is slightly acidic. As mentioned earlier, this acidity has been attributed to flaring of gas in the Niger Delta region [3,4,10]. TDS ranges were from 39.6 $\mathrm{mg} / \mathrm{L}$ at Unity School and Okan to a maximum of $123 \mathrm{mg} / \mathrm{L}$ at Ekrebe Unuode area. Sources of these TDS could be attributed to residential runoff from the surrounding area as well as recharge by rainfall. On the basis of the chemical constituent analyzed for, the groundwater can be considered as freshwater. Major cations $\mathrm{Na}^{+}, \mathrm{K}^{+}, \mathrm{Ca}^{2+}, \mathrm{Mg}^{2+}$ and major anions $\mathrm{HCO}_{3}{ }^{-}, \mathrm{Cl}^{-} \mathrm{SO}_{4}{ }^{2-}$ and $\mathrm{NO}_{3}{ }^{-}$were below the MPLs with the exception of magnesium at Okotie Avenue which is above the permissible limit. Magnesium concentration above the recommended limits has no health implications as the WHO 
standard [24] and has no upper limits set for magnesium concentration. The concentration levels of $\mathrm{Pb}, \mathrm{Cd}$ and $\mathrm{Cr}$ in groundwater were compared with the MPLs set by SON [23]. As shown in Table 3, lead occurs at levels that are well below the MPL of $0.01 \mathrm{mg} / \mathrm{L}$ and were undetected in $50 \%$ of the samples. Similarly, cadmium and chromium occurs at levels that are also below the MPLs of $0.003 \mathrm{mg} / \mathrm{L}$ and $0.05 \mathrm{mg} / \mathrm{L}$ and were undetected in $30 \%$ and $20 \%$ of the samples, respectively. Indeed, while elevated levels of $\mathrm{Pb}, \mathrm{Cr}$ and $\mathrm{Cd}$ have been reported in Warri and certain areas in the SWDP [3,9,10,25], this is not the case at Agbarho. A possible explanation to this would be the absence of oil and gas industry activities in the area as there are in the Effurun-Warri area located less than 10 $\mathrm{km}$ southwest of Agbarho and where elevated level of occurrence of these heavy metals in groundwater have been attributed to an existing refinery and petrochemical plant. Dumpsites have been shown to be rich sources of lead and cadmium in groundwater [26,27], large scale dumpsites are also absent from Agbarho. With regard to the microbial content of the water, the groundwater is generally coliform bacteria free in $80 \%$ of the area under study. However, dug wells at Unity School and Agbarho Town Hall contain faecal coliforms. The presence of faecal coliform restricted to these two wells may be attributed to the fact that the wells are kept in unsanitary conditions and are therefore expose to human and animal waste contamination.

Ground water and surface water supply sources are considered suitable for domestic purposes with minimal treatment. However, continuous water quality monitoring is essential if the shallow aquifer is to be used as a source of water supply.

Table 2. Physical and chemical characteristics of surface water from Agbarho River. Units in $\mathrm{mg} / \mathrm{L}$ except where indicated.

\begin{tabular}{llll}
\hline Parameters & ST1 & ST2 & SON (2015) \\
\hline $\mathrm{pH}$ & 4.9 & 5.4 & $6.5-8.5$ \\
$\mathrm{TDS}$ & 9 & 25.6 & 500 \\
$\mathrm{EC}(\mu \mathrm{s} / \mathrm{cm})$ & 17.8 & 51.4 & 1000 \\
$\mathrm{Ca}$ & 1.6 & 2.9 & \\
$\mathrm{Mg}$ & 0.7 & 1.6 & 20 \\
$\mathrm{~K}$ & 1.03 & 4.79 & \\
$\mathrm{Na}$ & 1.65 & 8.11 & 200 \\
$\mathrm{Cl}$ & 5.34 & 15.42 & 250 \\
$\mathrm{HCO}_{3}$ & 0.84 & 4.03 & \\
$\mathrm{SO}_{4}$ & 0.09 & 0.61 & 100 \\
$\mathrm{NO}_{3}$ & 0.13 & 0.23 & 50 \\
$\mathrm{~Pb}_{\mathrm{Cd}}$ & 0.00 & 0.00 & 0.01 \\
$\mathrm{Fe}$ & 0.001 & 0.001 & 0.003 \\
$\mathrm{Cr}$ & 0.02 & 0.24 & 0.3 \\
Total coliform (cfu/100 mL) & 0.00 & 0.00 & 0.05 \\
Faecal coliform (cfu/100 mL) & 0 & 6 & 10 \\
\hline ST1, Site 1; ST2, Site 2; SON, Nigerian Drinking Water Standard. &
\end{tabular}

ST1, Site 1; ST2, Site 2; SON, Nigerian Drinking Water Standard. 
Table 3. Physical and chemical characteristics of groundwater. Units in $\mathrm{mg} / \mathrm{L}$ except where indicated, coliform counts in (cfu/100 mL).

\begin{tabular}{llllllllllll}
\hline & \multicolumn{10}{c}{ Sampling locations } \\
\cline { 2 - 6 } & EKR & OKO & GEN & UNI & EKB & AGB & OBA & OKA & OGB & AKP & $\begin{array}{l}\text { SON } \\
(2015)\end{array}$ \\
\hline $\mathrm{pH}$ & 5.5 & 5 & 5.8 & 5.7 & 3.8 & 5 & 5.5 & 5.9 & 5.2 & 5.6 & $6.5-8.5$ \\
$\mathrm{TDS}$ & 88 & 103 & 51.1 & 39.6 & 123 & 98.6 & 67 & 39.6 & 61 & 120 & 500 \\
$\mathrm{EC}(\mu \mathrm{s} / \mathrm{cm})$ & 177.7 & 210 & 100.5 & 26.3 & 24.7 & 197.2 & 133 & 82 & 124 & 245 & 1000 \\
$\mathrm{Ca}$ & 19.3 & 23.06 & 9.10 & 4.2 & 2.6 & 27.5 & 13.6 & 7.3 & 14.4 & 27.4 & \\
$\mathrm{Mg}$ & 14.7 & 29.04 & 7 & 2.6 & 1.80 & 17.60 & 8 & 15.1 & 9.6 & 14.1 & 20 \\
$\mathrm{~K}$ & 15.02 & 17.04 & 9.33 & 2.02 & 16.51 & 18.33 & 7.3 & 4.01 & 8.1 & 17.02 & \\
$\mathrm{Na}$ & 19.74 & 24.11 & 14 & 5.07 & 27.13 & 24.06 & 12.02 & 6.73 & 15.49 & 25.99 & 200 \\
$\mathrm{Cl}$ & 53.31 & 63 & 30.15 & 15.75 & 74.1 & 59.16 & 39.9 & 24.6 & 37.2 & 73.5 & 250 \\
$\mathrm{HCO}_{3}$ & 16.09 & 17.18 & 11.04 & 3.18 & 21.98 & 14.61 & 11.75 & 5.81 & 13.56 & 23.9 & \\
$\mathrm{SO}_{4}$ & 0.41 & 1.06 & 0.38 & 0.29 & 1.44 & 0.78 & 0.80 & 0.56 & 0.91 & 1.07 & 100 \\
$\mathrm{NO}_{3}$ & 0.42 & 0.71 & 0.35 & 0.16 & 0.8 & 0.52 & 0.61 & 0.11 & 0.31 & 0.77 & 50 \\
$\mathrm{~Pb}$ & 0.001 & 0.000 & 0.000 & 0.000 & 0.000 & 0.003 & 0.001 & 0.001 & 0.000 & 0.002 & 0.01 \\
$\mathrm{Cd}$ & 0.000 & 0.001 & 0.000 & 0.001 & 0.001 & 0.002 & 0.001 & 0.001 & 0.000 & 0.002 & 0.003 \\
$\mathrm{Fe}$ & 0.21 & 0.17 & 0.17 & 0.04 & 0.43 & 1.3 & 0.18 & 0.08 & 0.38 & 0.84 & 0.3 \\
$\mathrm{Cr}$ & 0.001 & 0.000 & 0.001 & 0.001 & 0.001 & 0.002 & 0.001 & 0.000 & 0.001 & 0.002 & 0.05 \\
$\mathrm{Total}$ coliform & 0 & 0 & 0 & 1 & 0 & 3 & 0 & 0 & 0 & 0 & 10 \\
Faecal & 0 & 0 & 0 & 1 & 0 & 1 & 0 & 0 & 0 & 0 & \\
coliform & & & & & & & & & & & \\
\hline
\end{tabular}

EKR, Ekrerhervwe Street; OKO, Okotie Avenue; GEN, General Hospital; UNI, Unity School; EKB, Ekrebe Unuode; AGB, Agbarho Town Hall; OBA, Obada Street; OKA, Okan; OGB, Ogboru Akpoguma Street; AKP, Akpovi Avenue, SON, Nigerian Drinking Water Standard.

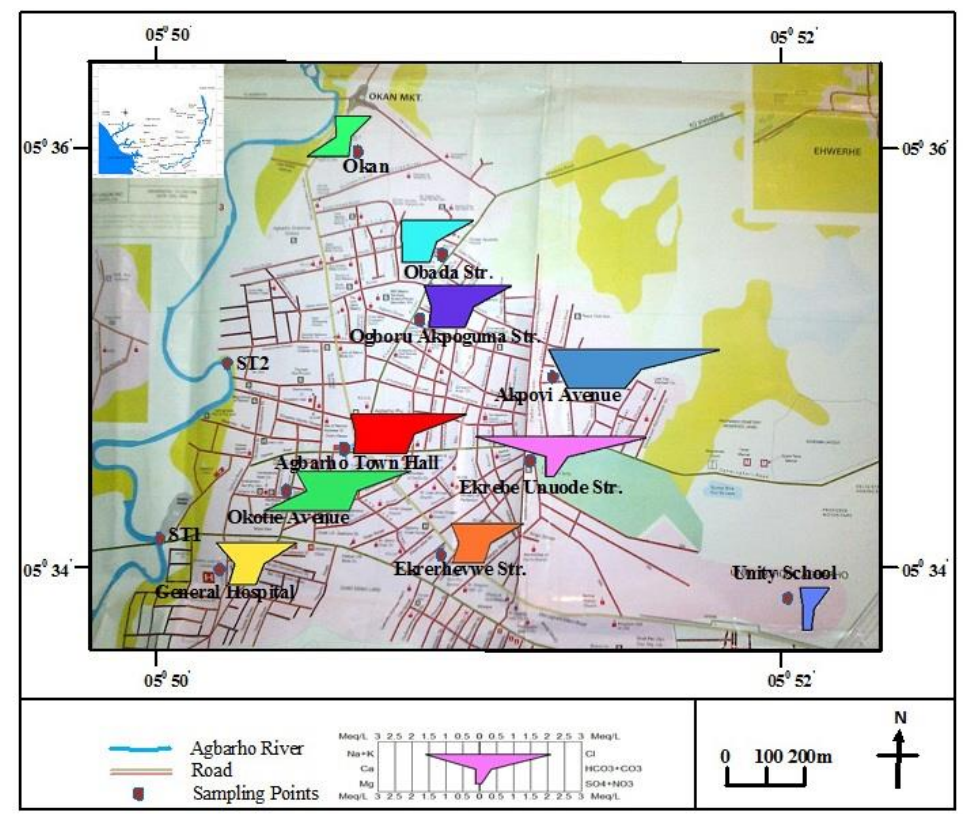

Fig. 4. Water sample locations and associated stiff diagrams (base map modified from [21]). 


\subsubsection{Major ion chemistry}

The Piper [28] and Stiff [29] diagrams have been widely used [20,30-36] as a descriptive tool to interpret and classify groundwater on the basis of the major ion contents. The Piper diagram plotted for the area is shown in Fig. 5 and associated major ion constituents used for the plot are presented in Table 3. All the samples plot in a straight line on the upper right corner of the diamond-shaped field that stretches from 50 to $80 \%$ calcium + magnesium, while sulphate + chloride are between 80 to $90 \%$ with an exception of Ekrebe Unuode (EKB) which is at the midsection to the right of the diamond. The plot reflects groundwater variability, indicating a mixing trend with precipitation (rainfall) as the main factor controlling the groundwater chemistry. Groundwater from Okan (OKA) may be classified as magnesium chloride type while at Ekrebe Unuode (EKB) is sodium chloride facie. For all other areas, it is of mixed type having no dominant cation.

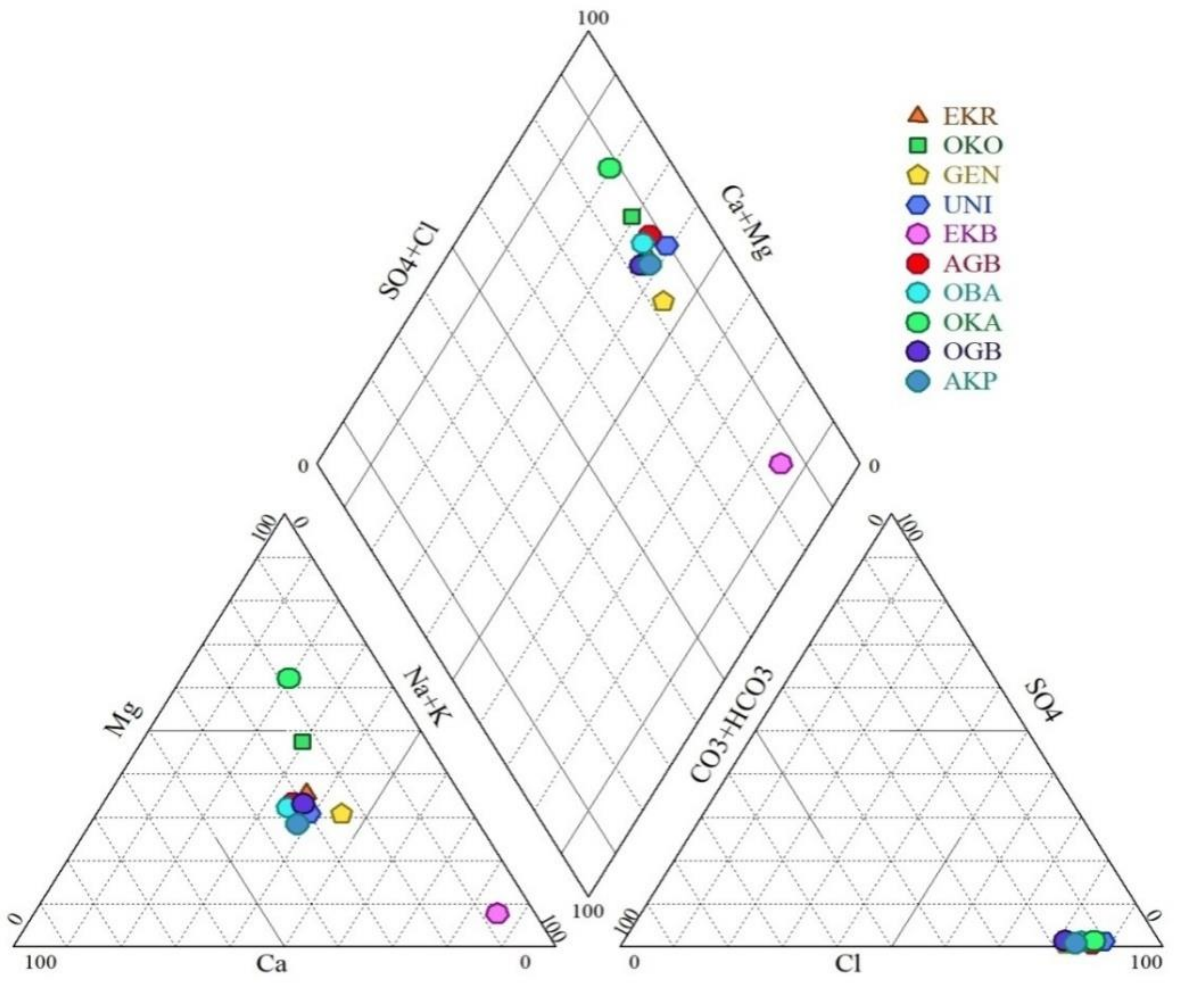

Fig. 5. Piper plot of groundwater analyses from Agbarho. EKR, Ekrerhervwe Street; OKO, Okotie Avenue; GEN, General Hospital; UNI, Unity School; EKB, Ekrebe Unuode; AGB, Agbarho Town Hall; OBA, Obada Street; OKA, Okan; OGB, Ogboru Akpoguma Street; AKP, Akpovi Avenue. 
The stiff diagram plotted for each sample location is superimposed on Fig. 4. The diagrams confirm further the differences in water types from dug wells in the area on the basis of their distinguishable shapes. The abundance of major cations are in the order of $\mathrm{Mg}>\mathrm{Na}+\mathrm{K}>\mathrm{Ca}(\mathrm{OKO}, \mathrm{OKA}), \mathrm{Na}+\mathrm{K}>\mathrm{Mg}>\mathrm{Ca}(\mathrm{GEN}, \mathrm{AGB}, \mathrm{OGB}, \mathrm{EKR}, \mathrm{UNI}, \mathrm{EKB})$ and $\mathrm{Na}+\mathrm{K}>\mathrm{Ca}>\mathrm{Mg}$ (AKP, OBA) respectively, while the abundance of major anions is in the order of $\mathrm{Cl}>\mathrm{HCO}_{3}>\mathrm{SO}_{4}$ for all the areas. Following the suggestion from earlier studies in the SWDP that the inverted funnel shape be considered representative of native and pristine groundwater in the Benin Formation outcrop areas [20], sample EKB (Ekrebe Unuode) fits this description and all others which are distorted from this shape have undergone changes. Indeed, at nearby Orerokpe which is adjacent to north of the study area, it has been shown that the main factor controlling the chemical composition of the groundwater in the area is infiltration of rainwater and associated weathering [8,37].

\section{Conclusion}

This study has described groundwater conditions and hydrogeochemistry of the shallow aquifer in the Sombreiro-Warri Deltaic Plain deposit in the Agbarho area. Depth to water level varies from 1.2 to $6.45 \mathrm{~m}$. Regional groundwater flow is from the northeast to southwest direction. Continuous groundwater abstraction in the core and more populated central area has resulted in local distortion of the regional northeast-southwest groundwater flow direction. The physical and chemical properties of surface water and groundwater are well below the drinking water permissible level with an exception of coliform bacteria in the surface water which are as a result of human and animal waste contamination. The water is considered fresh. The major ion chemistry revealed two hydrochemical facies, magnesium chloride $\left(\mathrm{MgCl}_{2}\right)$ and sodium chloride $(\mathrm{NaCl})$ facies.

\section{Acknowledgments}

The authors are grateful to the Center for Research in Environmental Resource Management, Abraka for providing partial funding and resources for this investigation.

\section{References}

1. T. K. S. Abam, Bull. Eng. Geol. Environ. 53, 13 (2007).

2. L. C. Amajor, Environ Geol Water Sci. 17, 85 (1991). https://doi.org/10.1007/BF01701565

3. I. A. Akpoborie, O. A. Ekakite, and E. O. Adaikpoh, Knowledge Rev. 2, 72 (2000).

4. S. B. Olobaniyi and F. B. Owoyemi, Water Resour. 15, 38 (2004).

5. A. F. Abimbola, S. A. Oke, and A. S. Olatunji, Water Resour. 13, 7 (2002).

6. B. O. Ejechi, S. B. Olobaniyi, F. E. Ogban, and F. C. Ugbe, Environ. Moni. Assess. 128, 495 (2007). https://doi.org/10.1007/s10661-006-9343-1

7. S. B. Olobaniyi, F. E. Ogban, B. O. Ejechi, and F. C. Ugbeh, J. Environ. Hydrol. 15, 1 (2007).

8. K. Aweto and I. A. Akpoborie, J. Appl. Sci. Environ. Manage. 15, 351 (2011). https://doi.org/10.4314/jasem.v15i2.68521

9. I. A. Akpoborie, Africa Geosci. Rev. 18, 25 (2011). https://doi.org/10.18356/6cfa613d-en 
10. I. A. Akpoborie, A. E. Uriri, and O. Efobo, Environ. Pollut. 3, 27 (2014). https://doi.org/10.5539/ep.v3n3p27

11. J. O. Adejuwon, J. Geogr. Reg. Plann. 5, 51 (2012). https://doi.org/10.5897/JGRP11.096

12. J. R. L. Allen, Bull. Amer. Assoc. Petr. Geol. 49, 547 (1965).

13. K. C. Short and A. J. Stauble, Bull. Amer. Assoc. Petr. Geol. 54, 761 (1967).

14. E. Oomkens, Sedimentology 21, 195 (1974). https://doi.org/10.1111/j.1365-3091.1974.tb02056.x

15. L. O. Asseez (Rock View (Nig) Ltd., Jos, 1975) pp. 311-324.

16. C. S. Nwajide, PTDF Chair (University of Nigeria, Nsukka, 2006).

17. APHA, $8^{\text {th }}$ Edition (Washington, D.C., 1992).

18. Golden Software Inc. Co. (USA, 2002).

19. Nigeria Geological Survey Agency (NGSA) (Abuja. Geological Map of Nigeria, 2006).

20. I. A. Akpoborie and O. Efobo, Int. J. Water Res. Environ. Eng. 6, 19 (2014). https://doi.org/10.5897/IJWREE2013.0446

21. Agbarho Urhobo Improvement Union Incorporation. A Map of Agbarho and Environs (2004).

22. A. N. Kaizer and S. A. Osakwe, J. Appl. Sci. Environ. Manage. 14, 83 (2010). https://doi.org/10.4314/jasem.v14i1.56501

23. Standards Organization of Nigeria (SON), NIS- 554:2015 (Abuja, 2015) pp. 28.

24. World Health Organization, $4^{\text {th }}$ Edition (WHO, Geneva, 2017).

25. G. E. Eriyamvemu, S. O. Asagba, I. A. Akpoborie, and S. I. Ojeaburu, Bull. Env. Contam. Toxicol. 75, 278 (2005). https://doi.org/10.1007/s00128-005-0749-1

26. E. O. Akudo, G. U. Ozulu, and L. C. Osogbue, Environ. Res. J. 4, 281 (2010). https://doi.org/10.3923/eri.2010.281.285

27. C. M. Iwegbue, G. E. Nwajei, J. E. Ogala, and L. C. Overah, Environ. Geochem. Health 32, 415 (2010). https://doi.org/10.1007/s10653-010-9285-y

28. A. M. Piper, Trans. Am. Geophys. Union 25, 914 (1944). https://doi.org/10.1029/TR025i006p00914

29. H. A. Stiff, J. Petrol. Technol. 3, 15 (1951). https://doi.org/10.2118/951376-G

30. M. Sherif, A. El Mahmoudi, H. Garamoom, A. Kacimov, S. Akram, A. Ebraheem, and A. Shetty, Environ. Geol. 49, 536 (2006). https://doi.org/10.1007/s00254-005-0081-4

31. S. A. Arabi, I. I. Funtua, S. A. Alagbe, P. Zabosrki, and B. B. M. Dewu, J. Am. Sci. 6,664 (2010).

32. I. Chenini, B. Farhat, and A. B. Mammou, Chem. Speciat. Bioavail. 22, 183 (2010). https://doi.org/10.3184/095422910X12829228276711

33. I. Cartwright and U. Morganstern, J. Hydrol. 475, 137 (2012). https://doi.org/10.1016/j.jhydrol.2012.09.037

34. Y. Hamed, R. Ahmadi, A. Demdoum, S. Bouri, I. Gargouri, H. B. Dhia, S. Al-Gamal, R. Laouar, and A. Choura, J. Afr. Earth Sci. 100, 418 (2014). https://doi.org/10.1016/j.jafrearsci.2014.07.012

35. Y. Chen, L. Wang, T. Liang, J. Xiao, J. Li, H. Wei, and L. Dong, Environ. Geochem. Health 41, 1091 (2019). https://doi.org/10.1007/s10653-018-0204-y

36. F. Ferdous, M. R, Rafiq, and M. I. Mahmud, J. Sci. Res. 8, 355, (2016). https://doi.org/10.3329/jsr.v8i3.25360

37. R. J. Gibbs, Sciences 170, 1088 (1970). https://doi.org/10.1126/science.170.3962.1088 